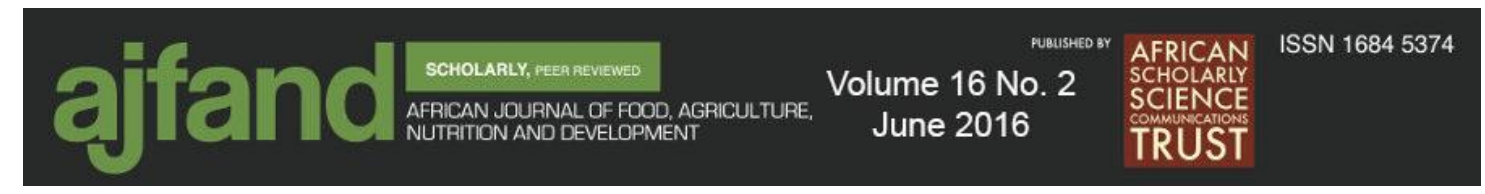

DOI: 10.18697/ajfand.74.15770

\title{
FERTILISER CREDIT AND AGROECOLOGICAL USE OF ORGANIC SOIL AMENDMENTS IN NORTHERN GHANA
}

\section{Bellwood-Howard I ${ }^{*}$, Al-hassan $\mathbf{S}^{1}$}

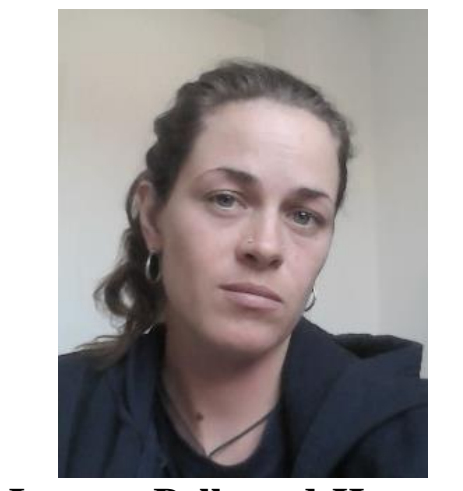

Imogen Bellwood-Howard

*Corresponding author's email: $\underline{\text { ibellwoodh@gmail.com }}$

${ }^{1}$ Institute for Continuing Education and Interdisciplinary Research, University for Development Studies, PO Box 1350, Tamale, Ghana 


\section{ABSTRACT}

Contemporary African agricultural policy embodies the African Green Revolution's drive towards modernisation and commercialisation. Agroecologists have criticised this movement on ecological, social and political grounds. Northern Ghanaian fertiliser credit schemes provide a good example through which these critiques can be examined in a context where agricultural policy reflects the African Green Revolution's ideals. This study aimed to determine the relationship of such credit schemes to farmers' use of organic amendments, elucidate other factors related to organic amendment use, and comment on the relevance of this modernisation policy and its relationship to agroecology. A first research phase employed semi-structured key informant interviews. Qualitative data from these informed construction of a semi-structured questionnaire that was used in a survey of 205 farmers. Multistage sampling purposively identified five villages and selected farmers within who had joined government and donor-funded fertiliser credit schemes. The use of organic and inorganic amendments was compared to that of peers who had not taken part in such schemes. Quantitative data were used in binomial logistic regression, inferential and descriptive statistics. Qualitative data were content analysed. Credit group membership was associated with higher fertiliser application and yield, but had little influence on the extent of commercialisation. Farmers who applied organic amendments were $40 \%$ less likely to belong to a fertiliser credit scheme than not, indicating substitution between organic and inorganic fertilisers. Organic amendments were $40 \%$ more likely to be applied to compound farms than outfields and six times more likely to be applied by household heads than other household members. However, household heads also preferentially joined credit groups. This was part of an agroecological soil fertility management strategy. Household heads appreciated the soil moisture retention properties of organic amendments, and applied them to compound farms to reduce risk to their household food supply in a semi-arid environment. They simultaneously accessed fertiliser to enhance this household provisioning strategy. They appreciated the increased yields this achieved, yet complained that the repayment terms of credit schemes were unfair, fertiliser did not enhance yields in dry conditions and fertilisers were supplied late. Farmers' use of credited fertiliser alongside their existing agroecological strategy is helpful to the extent that it raises yields, yet is problematic in that it conflicts with risk-reduction strategies based on organics. There is some potential for modernised and agroecological management paradigms to coexist. For fertiliser credit to play a role in this, schemes must use fairer repayment terms and involve a focus on simultaneous use of organic amendments.

Key words: Agroecology, compost, Ghana, fertiliser credit, Soil Fertility Management, maize 


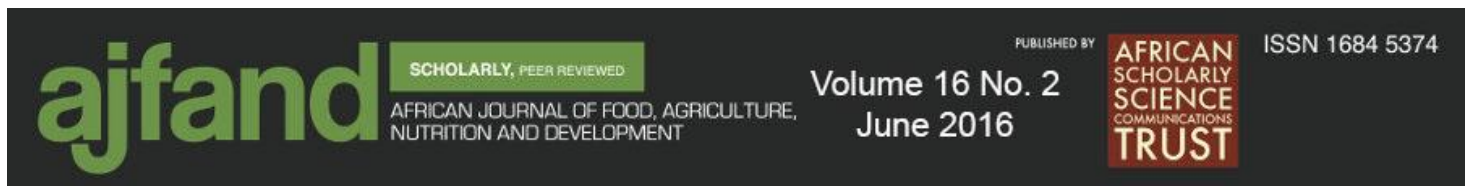

\section{INTRODUCTION}

African agriculture has been commercialised and modernised in the 21 st century. This is typified by the African Green Revolution movement, which aims at increasing yields through modern technologies [1]. These ambitions are reflected in policy, for example the 2015 renewal of the African Union's 2003 Comprehensive African Agriculture Development Programme. However, critiques of this development endeavour echo the controversy that surrounded the 1960s Asian Green Revolution, highlighting the social impacts of introducing new agricultural technologies without appropriate financial and institutional support [2]. For example, credit is posited as dangerous, in that it risks indebting farmers [3]. Environmental sustainability is another concern, with fears that long-term inorganic fertiliser use prevents soil organic matter regeneration as farmers abandon organic amendments, and that high-input agricultural regimes raise risks of crop failure $[3,4,5]$.

Such concerns invoke an agroecological management paradigm. The science of agroecology considers interactions between ecological, social, political and economic elements of agricultural systems. Agroecology is simultaneously a political movement, promoting farmers' rights and advocating organic methods [6]. Political agroecologists consider that the African Green Revolution involves a simplistic, technology-driven development agenda based on an outdated modernisation paradigm, and criticise 'attempts to co-opt agroecology into the Green Revolution', claiming that it threatens food sovereignty [7].

African Green Revolution proponents have attempted to deflect such critiques. The Alliance for a Green Revolution in Africa (AGRA), for example, incorporates institutional and financial innovations into its 'Innovative Financing' and 'Market Access' programs, intending to help farmers adopt technology and commercialise without becoming indebted [8]. Linked to this, credit has been disbursed by states, NGOs and private ventures, often in Public-Private Partnerships.

This study, therefore, assesses the relevance of these agroecological critiques of the African Green Revolution through a case study of northern Ghanaian fertiliser credit schemes. This permits examination of how modernist and agroecological management paradigms interact in a current development context. Fertiliser credit schemes are a particularly appropriate case example for this, because they involve ecological, financial and social elements, whilst embodying one of the African Green Revolution's central technologies - Integrated Soil Fertility Management (ISFM) [9]. This advocates use of a mixture of inorganic and organic fertilisers and improved germplasm, with inorganic fertiliser as the entry point to improved soil fertility management. Integrated Soil Fertility Management recognises the synergistic and non-substitutable effects of organic and inorganic fertilisers [10]. It is also understood that local knowledge and institutional and socio-political elements are integral to effective soil management $[3,11]$.

Northern Ghana was an appropriate setting for this study because Ghanaian agricultural policy reflects African Green Revolution ideals. The 2009 Northern Regional Growth Programme, supported by the International Fund for Agricultural Development, and the 
2012 USAID-funded Ghana Commercial Agriculture Programme both assume that access to markets and credit will increase Northern smallholders' food security. The Agricultural Value Chain Mentorship Project, a Public-Private Partnership, aims to 'link farmers to commercial banks to access capital through loans' [12]. Out-grower models include the Ghana Grains Partnership between the Government, fertiliser wholesalers Wienco and Yara, their smallholder cooperative Masara N'Arziki and the broker Prorustica [13]. In 2013 the Ghana Grains Council implemented a warehouse inventory receipt system, in which farmers use stored grain as loan collateral.

Northern Ghana has a particularly strong agricultural tradition. Agriculture employs over $70 \%$ of the regional labour force [14] and its form reflects patterns common across Africa. The main staple is maize, often intercropped with groundnuts, the major cash crop. Household heads of the patriarchal Dagomba ethnic group (henceforth 'landlords') combine crops and livestock on holdings of two to ten acres. They are responsible for providing maize to their households [15]. Junior men ('nachimbihi') grow groundnuts, rice and vegetables for cash. Northern Ghanaian agriculture is, nevertheless, still largely semi-subsistence and nachimbihi assist landlords on household farms before attending to their own. Landlords and nachimbihi also use paid and reciprocal labour.

The Guinea savanna climate has one rainy season of 4-6 months, within which precipitation can be unpredictable. Soils in the study region are sandy with organic matter content typically below $2 \%$ [16]. Soil fertility is, therefore, low and maize fertilisation, usually with compound and ammonia fertilisers, is considered essential. However, despite subsidisation between 2008 and 2015, the cost remains a constraint. As mentioned, exclusive inorganic application means topsoil organic matter does not regenerate thus reducing soil moisture retention capacity. Some farmers, therefore, use organic amendments, mostly manure and compost. This is constrained by limited availability and transportation difficulties, so organics are applied mostly to compound or 'sambanni' farms close to the homesteads, rather than to more remote outfields, as is common across West Africa [17]. Farmers occasionally use other techniques such as mulching and, rarely, fallowing.

Strategies reflecting Green Revolution discourses are emerging in the study villages. Credit is available through the Ministry of Agriculture (MOFA) and various NGOs, notably Campaign for Agricultural and Rural Development (CARD), supported in 2012 by the Millennium Development Agency (MiDA), the Ghana 'compact' of the USA's Millennium Challenge Corporation. The Millennium Development Agency made funds available to the Bank of Ghana, which selected and disbursed cash to implementers such as CARD. Both the MOFA and MiDA/CARD schemes worked through farmer groups. There have been calls for examination of the effect of such modernisation and commercialisation endeavours on soil fertility management at local scales $[11,18]$. In order to address this issue, this study posed the following research questions:

1. Do farmers who are members of credit schemes achieve higher yields or sell a higher proportion of their goods?

2. Is scheme membership associated with a difference in application of organic and inorganic amendments? 


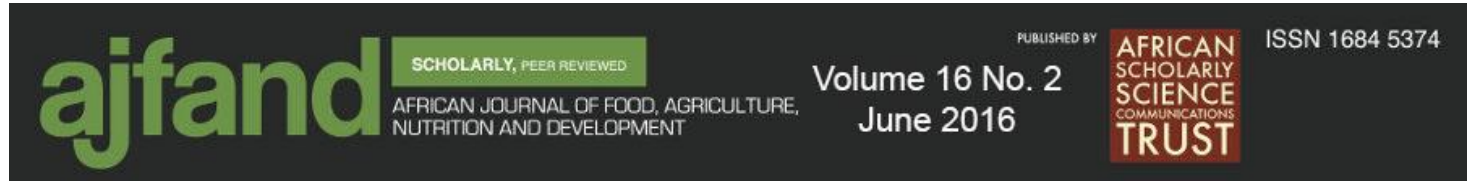

3. Which factors other than credit scheme membership influence organic and inorganic fertiliser application?

4. What are farmers' opinions about fertiliser credit schemes?

\section{METHODS}

Fieldwork took place $25 \mathrm{~km}$ north of the Northern Ghanaian regional capital, Tamale, between January and March 2012.

\section{Sampling}

Multistage sampling was done at district, community and individual levels. Two districts, Kumbungu and Savelugu-Nanton, were selected from the Northern maize producing districts. These districts are close enough to the large city, Tamale, for input and output markets to function, facilitating examination of commercialisation. A spatial cluster of five accessible communities was identified where farmers had participated in credit schemes (see Figure 1). This kept agroecological and cultural characteristics of the sample fairly homogenous, as variation in these was not the main focus. The last sampling level involved maize farmers. The sampling procedure at this level differed for qualitative and quantitative data collection. 

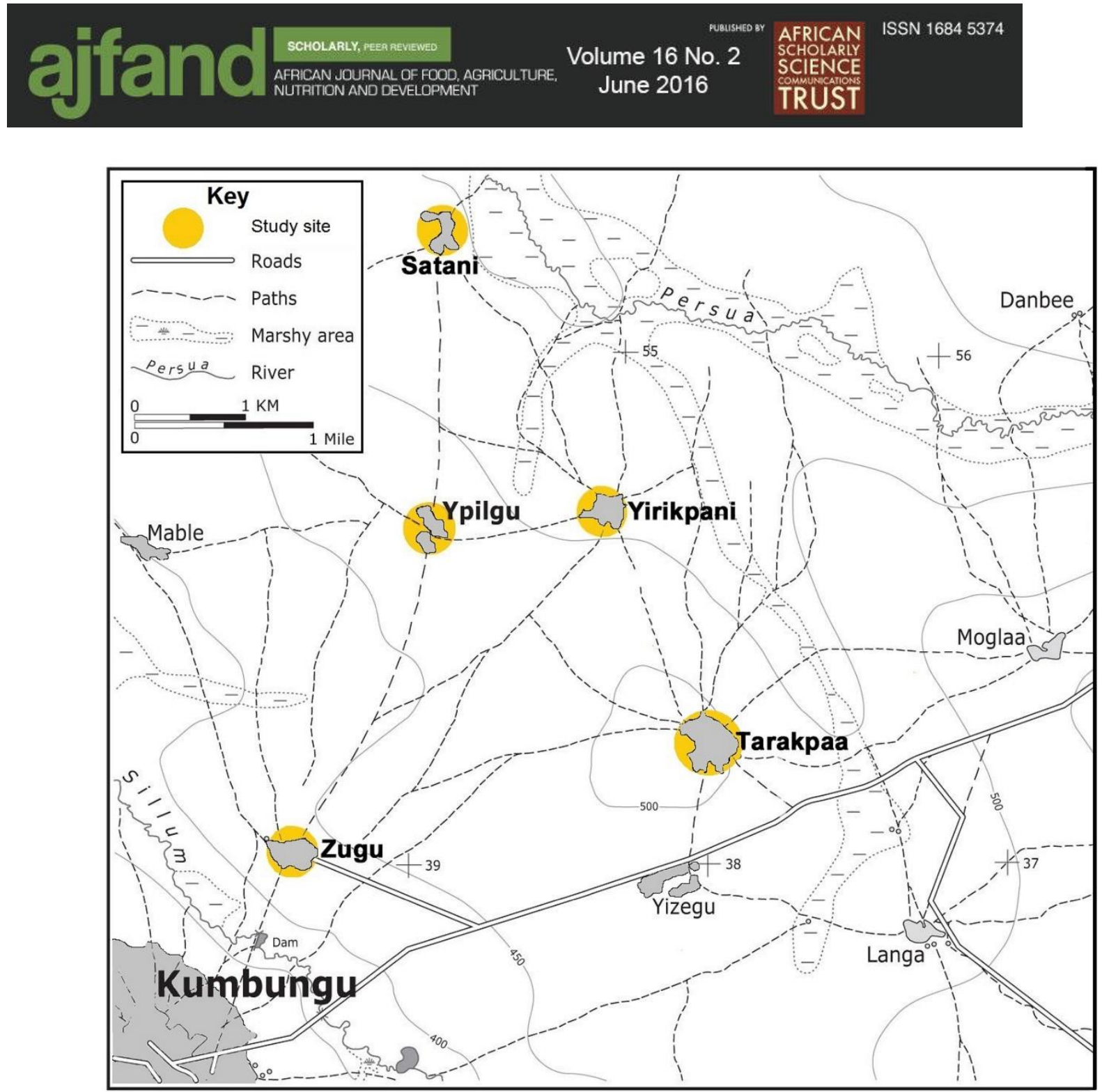

Figure 1: Study site location (Source: Survey of Ghana, updated 2015 from Google Earth)

\section{Data collection and tool design}

At the farmer level, respondents for semi-structured interviews were purposively sampled in a first research stage. These interviews sought qualitative data on the opinions and experiences of key respondents on fertilisation, commercialisation and credit [19]. In Zugu, Satani and Tarakpaa, these were contact farmers from the Millennium Development Agency and Ministry of Agriculture schemes. Employees from MiDA and one from CARD were also interviewed, alongside three from MOFA. Interview topic guides focused on scheme aims and operation; interviewee's opinions of their efficacy and drawbacks, and factors they considered influenced farmers' soil fertility management practice.

The second research stage involved a structured survey of 205 farmers, collecting their answers to specific questions about their fertilisation practice [20]. Here, a sampling procedure resembling the 'nearest neighbour' method was used. Credit group members were contacted through group chairmen and matched to others who were not members 
on the basis of approximate age, household size and household role [21, 22]. Those nonscheme members were recruited through household visits, where verbal consent was obtained. The farmers sampled for the survey comprised approximately five percent of the population of the five villages, based on an estimate of approximately 20 household members in each house in the communities (see Table 2). Table 1 gives numbers of farmers sampled in each village.

Interview data from the first research stage informed the design of the survey questionnaire, particularly the identification of variables that could influence the use of organic amendments. The first section detailed respondents' demographic and socioeconomic characteristics. The second asked for the number of bags of different types of fertiliser from different sources they had applied to each of their fields. Thirdly, the output of each field was ascertained and other soil fertility management strategies listed. In the final section, respondents gave their opinions about fertiliser and credit schemes.

During pre-testing, farmers could not state financial incomes or expenditures. An asset index is more appropriate in such situations where consumption of household produce dominates [23]. For ease of construction, an additive index was used, summing together the number of assets respondents could access from a list of relevant items. The list avoided assets that, in this context, were homogenous, including access to water and healthcare. Weighting assets equally is problematic [24], so several were kept scalar rather than being converted to dummies. Others were weighted based on the results of qualitative interviews and observations in the study context, as price data was not consistent [25]. Thus, cattle, motorbikes and tractors, expensive, elite goods, were weighted with 2 and 3 . The first section of the questionnaire was redesigned to facilitate the calculation of this index, as follows:

$$
\begin{aligned}
& \text { Asset index = number of small ruminants + (number of cattle x } 2)+ \text { household } \\
& \text { cattle ownership (dummy) + personal landholding (acres) + bicycle ownership } \\
& (\text { dummy) + alternative employment (dummy) + zinc roof (dummy) + (dummy } \\
& \text { for motorbike ownership x } 2)+(\text { dummy for tractor ownership x } 3)+\text { number } \\
& \text { of wives + number of children }
\end{aligned}
$$

[equation 1]

\begin{abstract}
Analysis
Analysis began with binomial logistic regression and Mann-Whitney $U$ tests, performed with SPSS 16. These indicated differences in yield, commercialisation and use of organic amendments between farmers who did and did not belong to credit groups, addressing research questions 1 and 2 .
\end{abstract}




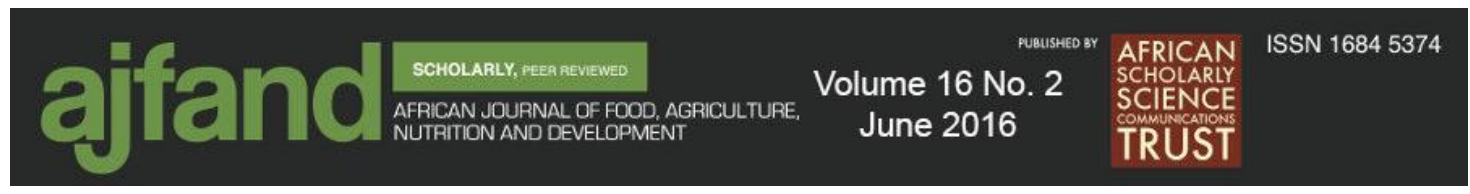

The logit model used is

$$
\ln \left[\frac{P}{1-P}\right]=\propto_{0}+\beta_{1} x_{1 i}, \ldots, \beta_{n} x_{n i}+\mu_{i}
$$

[equation 2] [26]

so here

$$
P=\frac{1}{1+e^{-\alpha_{0}+\beta_{1} x_{1 i}, \ldots,+\beta_{n} x_{n i}+\mu_{i}}}
$$

[equation 3]

where the dependent variable $\mathrm{P}$ is the probability that a farmer belongs to a credit group. The independent variables $\mathrm{x}_{1}$ to $\mathrm{x}_{5}$ are the number of bags of fertiliser they applied, the percentage of their output they consumed, the percentage they sold, their yield per household member, and a dummy indicating whether a farmer applied organic amendments at all.

Addressing research question 3 , a second binomial logistic regression was used to indicate which variables, identified from interviews and literature, were associated with use of organic amendments on specific fields. This had the same form as in equation 2 . The dependent variable is the probability of applying organic amendments. The independent variables $\mathrm{x}_{1}$ to $\mathrm{x}_{6}$ are four dummy variables indicating whether the field is a sambanni or an outfield, whether the farmer is a member of a fertiliser credit group, whether they are a landlord and whether they own a bicycle; and two scalar variables indicating their score on the asset index and the number of animals they own.

The comments and statements that farmers made in the qualitative section and in conversation were coded. Farmers made unambiguous statements that were assigned to subject categories post hoc, addressing research question 4 .

\section{RESULTS}

Table 2 details demographic characteristics of the sample. Parameters relating to the wealth of the sampled respondents are given in Table 3. Maize farmers were overwhelmingly male, with some livestock keeping and additional employment. Asset ownership was positively skewed.

Seventy-three percent of respondent credit scheme members were receiving credit from CARD. At harvest, farmers repaid in cash or maize with a bag of compound fertiliser being worth 1.5 sacks of maize and farmers repaying a bag of ammonia with a single sack of maize. The sanction for non-repayment was non-eligibility to borrow again. Nineteen percent of scheme members participated in a Ministry of Agriculture scheme 
using the same repayment rates, but with no sanction for non-repayment. The remaining eight percent had either borrowed privately or from one of four groups, associated with the NGOs Community Action Programme for Sustainable Agriculture and Rural Development and Adventist Development and Relief Agency or with local cotton and mango outgrowers.

\section{Credit, yield and commercialisation}

Binomial logistic regression answered the first research question of whether probability of being in a credit scheme was associated with raised yields or commercialisation. The initial $-2 \log$ likelihood was 282.78 and the $-2 \log$ likelihood at step 1 was 251.61 , giving a model chi-square of 31.17 (d.f. $=5, \mathrm{p}=0.000$ ). The Nagelkerke $\mathrm{R}^{2}$ was 0.189 and $70.1 \%$ of cases were predicted correctly, compared to $50.5 \%$ in the null model. Table 4 gives coefficients of the independent variables.

Farmers who produced higher yields per household member were more likely to be credit group members. However, selling a higher proportion of their crops did not mean a farmer was more likely to belong to a credit group. Farmers who consumed a higher proportion of their maize were slightly less likely to be group members. Coefficients close to 1 for these two latter variables indicate that being in a credit group had little effect on farmers' commercial orientation. Farmers described how the sales they did make occurred within four months of harvesting, before prices began to rise towards the next farming season. Table 5 shows that group members did receive a higher mean maize price. This was due to two farmers who transported their maize to Techiman, $200 \mathrm{~km}$ southwards, receiving up to 85 Ghana Cedis (GHS) (44.2 USD in March 2012) per sack compared to their colleagues' mean of 52 GHS (27.0 USD).

Farmers, and especially landlords, were subsistence oriented. Table 6 displays farmers' comments that indicated most perceived maize as a subsistence crop.

\section{Credit and Soil Fertility Management}

Answering question 2, Table 4 shows that a higher probability of scheme membership was associated with higher fertiliser application but not with organic amendment use. Group members used less borrowed fertiliser and bought less fertiliser (Table 5). Farmers were substituting the fertiliser they borrowed for organic amendments.

\section{Household role, farm position and Soil Fertility Management}

Detailed data collected at individual field level were used in the second binomial logistic regression to answer the third question of which farmer and field factors other than credit scheme membership influence organic fertiliser application. The initial -2 log likelihood was 321.69 and the $-2 \log$ likelihood at step 1 was 270.45 , giving a model chi-square of 51.24 (d.f. $=6, p=0.000$ ). The Nagelkerke $\mathrm{R}^{2}$ was 0.242 and $79.9 \%$ of cases were predicted correctly, compared to $75.3 \%$ in the null model. Table 7 gives coefficients of the independent variables.

Field location was most strongly related to the probability a field received organic amendments. Landlords, the male household heads, were also more likely to apply organics than junior household members, as were farmers who scored higher on the asset 
index. Transport was one component of that index facilitating organic application [27]. However, merely owning a bicycle was not associated with higher probability of organic application. As nachimbihi are more likely to own bicycles than landlords, bicycle ownership most likely acted here as an indication of junior household position. Similarly, animal ownership did not increase the probability that a farmer would apply organics. These two results indicate that it was more the landlords' food provisioning responsibility than access to transport and animal ownership that encouraged them to use organics. The negative association between credit group membership and application of organic amendments further substantiates the suggestion that farmers substituted subsidised inorganic fertiliser for organic amendments.

Examining household role reveals some of the relationships between group membership, inorganic and organic fertilisation and commercial or subsistence orientation. Almost $42 \%$ of landlords as opposed to $17.7 \%$ of nachimbihi used organics. However, landlords also preferentially used fertiliser credit: $55 \%$ of the credit group members sampled were landlords, whereas a census performed by the author in Yipielgu village in 2009 showed that just $24 \%$ of adult males were landlords.

Further statistics confirmed the importance of spatial location in farmers' fertilisation strategies. Solely organic amendments were applied to $39.5 \%$ of sambanni fields and just $2.4 \%$ of outfields. Conversely, fertiliser alone was applied to $74.7 \%$ of outfields and $30.2 \%$ of compound farms. Half of those who applied organic amendments to their own fields rotated their application either within or between them, generally annually. Six percent of the sample practiced such rotation on a household scale. In addition, $83 \%$ of all farmers used crop rotation, $56 \%$ of those between the fields of all farmers in the household.

These spatial management strategies were little altered by access to fertiliser credit. Neither bought nor borrowed fertiliser was preferentially applied to in- or outfields. Nearly $91 \%$ of fields receiving borrowed fertiliser were outfields, not significantly more than the $86 \%$ of fields that received bought fertiliser. Both infields and outfields fertilised with borrowed fertiliser were very slightly and not significantly less likely to receive organics than those fertilised with bought fertiliser alone or a mixture of the two.

\section{Farmers' opinions}

Addressing research question 4, on farmers' opinions, Table 8 shows that over $90 \%$ appreciated that fertiliser credit improved yields. They had ecological, logistical and financial concerns.

Farmers considered inorganics risky in an environment with low rainfall and soil fertility and explained that timely fertiliser application was critical for high yields. When the Campaign for Agricultural and Rural Development realised that funds would not arrive from the Bank of Ghana in time for the start of the season, they purchased fertiliser themselves, trusting the bank to repay them. Nevertheless, many farmers complained that the fertiliser had arrived too late. Ministry of Agriculture officials said that this complaint was even more pertinent in the case of the government-run schemes. 
Farmers' financial concerns deserve explanation. Repayment of bags of ammonia fertiliser with one sack of maize and compound fertiliser with 1.5 sacks has been described. In 2012, bags of subsidised compound were sold on the market for 39 GHS (20.3 USD) and ammonia for 35 GHS (18.2 USD). Sacks of maize used for repayment were, therefore, worth between 26 GHS (13.5 USD) and 35 GHS (18.2 USD), compared to the average of 52 GHS (27.0 USD) farmers earned when they sold a sack of maize on the market. Having spent all their cash on other farming costs, especially tractor hire earlier in the season, the majority of farmers repaid in maize. The losses they incurred in doing so meant that fertiliser use was not profitable for them: in 2012, the farmers participating in the survey lost on average 103.28 GHS (53.7 USD) by using maize for fertiliser repayment rather than selling it on the market. The benefits of increased yield that they ascribed to fertiliser credit were thus recouped not by them but by their creditors.

\section{DISCUSSION}

\section{Mixed support for the African Green Revolution}

The answer to research question 1 partially supports African Green Revolution narratives. Farmers who access credited fertiliser have less need to buy and borrow fertiliser elsewhere. They apply more overall, so achieve higher yields, as has been found elsewhere [28]. Here, credit does not increase the likelihood of commercialisation overall. Of those selling their maize, just two transported it outside the local area in order to raise its value. Most respondents stated they did not see maize as a commercial crop, and as these sales took place less than four months after harvest, it is more likely that many sold immediately to repay farming debts. This substantiates the idea that some, but not all, elements of the African Green Revolution are taking root in the study site.

As farmers see themselves as subsistence oriented, a change in their self-perception would be necessary to effect a switch to the African Green Revolution model of commercial trade and profit maximization. Many households here commercialise only after food security is guaranteed, largely because the current subsistence system deals better with risk.

\section{Subsistence risk reduction mechanisms}

These farmers already have an agroecological soil fertility management system that reduces risk, revealed through spatial field level data: farm location and household role were more strongly linked to use of organic amendments than credit group membership was. In a pattern found across West Africa, landlords preferentially apply organic amendments to compound farms, requiring less labour than carrying them to outfields [17]. They are the most appropriate people to take responsibility for this due to their control over family labour. Preferentially applying organics to compound farms can potentially deplete nutrient levels in outfields [29]. Farmers in the study area attempted to avoid such effects by rotating organic application between their outfields and compound fields.

Landlords have hitherto used organic amendments because they have a specific ecological importance in reducing drought risk, as they improve soil structure and 
moisture retention capacity [30]. This is especially significant in this erratic rainfall environment, confirmed by farmers' recognition of inorganic fertilisers' uselessness in drought. Landlords' use of organic amendments thus illustrates the African smallholders' propensity towards risk minimisation, also noted in Northern Ghanaian farmers' preference for landrace maize varieties [4]. The significant relationships between applying organic amendments, eating a higher proportion of their maize and selling a significantly lower proportion of it further demonstrates landlords' subsistence orientation. Inorganic fertiliser is another tool landlords can use to fulfil their household provisioning responsibilities, and accessing a credit groups supports this.

\section{Problems associated with fertiliser credit schemes}

Fertiliser credit, however, is used at the expense of organic-based risk reducing strategies. This is potentially problematic considering the ecological importance farmers afforded organics. Farmers' concern about the untimely supply of credited fertiliser related to their understanding of its agroecological function. They emphasised that fertilisers had to be applied on time to be useful, yet most were unable to achieve this due to the failure of the state and partnership mechanisms to deliver promptly.

Although this study did not aim to directly address issues of inequality, farmers raised them. The perceived unfair repayment rates of the credit schemes led some to echo critical authors' concerns that the African Green Revolution's underlying motivation is profit-making for input suppliers, and that Green Revolution technologies accentuate existing inequalities [5]. The wealthiest farmers encountered avoided the schemes. They argued that this advantaged them, as they were not indebted and could sell maize and obtain fertiliser at better prices. These concerns led farmers to treat credit not as a route into commercialisation but another risk they take to get inputs for subsistence.

These concerns were probably part of the reason that fertiliser credit groups had not totally eliminated the agroecological system. Farmers were still applying compost and manure to sambanni fields and both borrowed and bought fertiliser to outfields. Credit schemes' enhancement of yields and their existence alongside this agroecological system could be seen as a demonstration of farmers' ability to combine elements of modernised and agroecological soil fertility management strategies. To some extent this resonates with Bornstein's 2014 study that does not challenge the political agroecological view that the African Green Revolution is a penetration of capital into the countryside, but describes how farmers use the seeds it provides within existing storage and sharing arrangements [31]. Nevertheless, the indication that credit schemes are associated with lower likelihood of using organics is less positive.

\section{Future pathways}

Credit schemes raise fertiliser use and yield but not commercialisation, possibly because farmers are not confident that affordable staples are available through the market for purchase with the proceeds of maize sales. They, therefore, largely maintain their lowrisk subsistence strategy, using credit alongside it. If credit schemes reduce the prevalence of these existing agroecological mechanisms, they are risky. To be fully effective, fertiliser schemes should be combined with strategies to maintain existing 


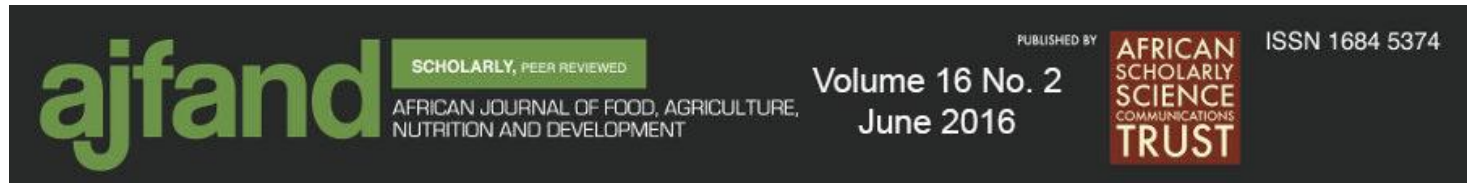

organic amendment applications by tackling logistical obstacles to higher application rates. Simultaneously, they should permit timely application and use fair repayment rates.

\section{CONCLUSION}

This study aimed to explore the relationship between fertiliser credit and farmers' use of organic amendments, thereby commenting on the interactions of modernising and agroecological management paradigms. The details of local agroecological soil fertility management practice and the roles of organic and inorganic amendments were illustrated when detailed spatial field level data were combined with quantitative and qualitative socioeconomic information and deep knowledge of the farming system. These data were treated with content analysis and binomial logistic regression, finding that fertiliser credit schemes increased inorganic input use and yields, but did not enhance commercialisation and were less important than existing socio-ecological and spatial factors in influencing how organic amendments were used. This demonstrates that fertiliser credit schemes, like other modernisation efforts of the African Green Revolution, can and should augment, but not supplant, existing agroecological systems.

\section{ACKNOWLEDGEMENTS}

Adam Abukari and Baba Alhassan provided invaluable assistance in questionnaire enumeration and interview translation. 


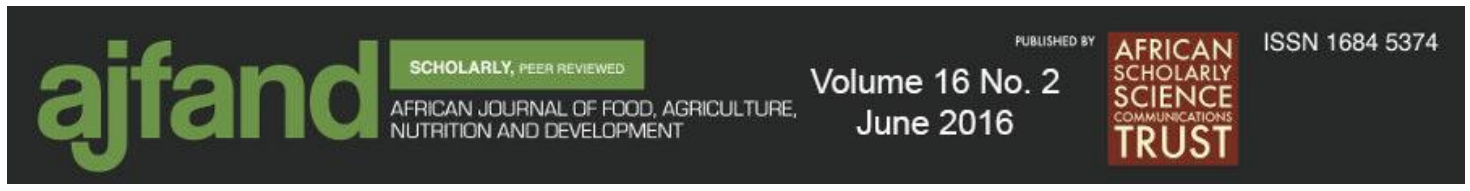

Table 1: Sampling statistics

\begin{tabular}{lll}
\hline Village & Number of farmers sampled & Percentage of farmers sampled \\
\hline Satani & 48 & 23.4 \\
Zugu & 55 & 26.8 \\
Yirikpani & 49 & 23.9 \\
Tarakpaa & 24 & 11.7 \\
Ypilgu & 29 & 14.1 \\
\hline Total & 205 & 100.0
\end{tabular}




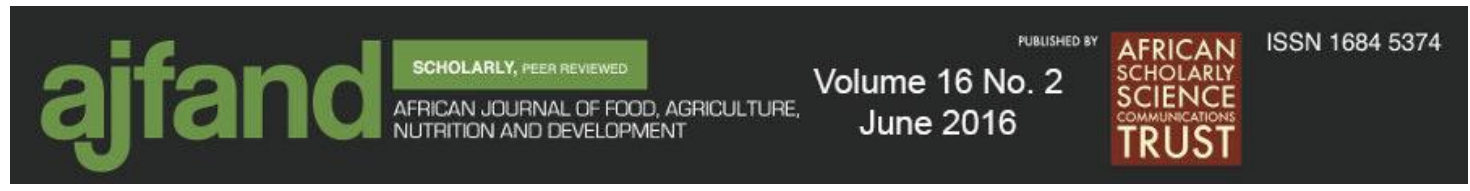

Table 2: Demographic sample characteristics

\begin{tabular}{|c|c|c|c|c|c|}
\hline & Mean $( \pm$ SE $)$ & Median & Mode & Minimum & Maximum \\
\hline Estimated age & $41.2( \pm 12.3)$ & 40 & 30 & 20 & 70 \\
\hline $\begin{array}{l}\text { Household } \\
\text { population }\end{array}$ & $20.5( \pm 12.0)$ & 18 & 30 & 3 & 70 \\
\hline Number of wives & $1.5( \pm 2.2)$ & 1 & 1 & 0 & 4 \\
\hline Number of children & $5.7( \pm 5.1)$ & 4 & 2 & 0 & 24 \\
\hline Household role & Frequency & & \multicolumn{3}{|c|}{ Percentage of sample } \\
\hline Landlord & 101 & & 49.3 & & \\
\hline $\begin{array}{l}\text { Joint or acting } \\
\text { landlord }\end{array}$ & 8 & & 3.9 & & \\
\hline Landlord's wife & 2 & & 1.0 & & \\
\hline Landlord's brother & 22 & & 10.7 & & \\
\hline Landlord's son & 53 & & 25.9 & & \\
\hline Landlord's nephew & 16 & & 7.8 & & \\
\hline $\begin{array}{l}\text { Landlord's } \\
\text { grandson }\end{array}$ & 2 & & 1.0 & & \\
\hline
\end{tabular}




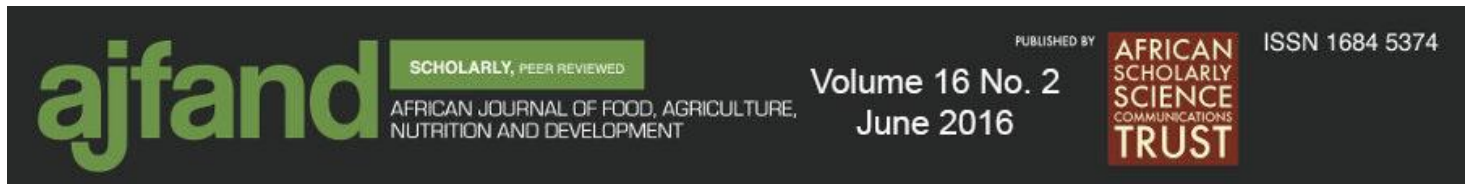

Table 3: Wealth-related sample characteristics

\begin{tabular}{lllll}
\hline Wealth indicator & Mean $( \pm$ SE) & Mode & Minimum & Maximum \\
\hline Number of sheep, goats and pigs & $7.4( \pm 10.4)$ & 0 & 0 & 100 \\
Number of cows & $2.6( \pm 8.4)$ & 0 & 0 & 100 \\
Personal landholding (acres) & $7.5( \pm 6.8)$ & 5 & 1 & 72 \\
Household landholding (acres) & $20.0( \pm 19.0)$ & 20 & 2 & 110 \\
Wealth index & $30.6( \pm 32.4)$ & 22 & 4 & 368 \\
\hline & Frequency & & Percent & \\
\hline Owns a bicycle & 182 & 88.0 & \\
Owns one motorbike & 65 & 31.7 & \\
Owns a tractor & 4 & 2.0 & \\
House roofed with zinc & 152 & 74.1 & \\
Has a job other than farming & 43 & 21.0 & \\
\hline
\end{tabular}

Table 4: Regression coefficients

\begin{tabular}{llcccc}
\hline & B & S.E. & Wald & Sig. & Exp(B) \\
\hline $\begin{array}{l}\text { Whether organic matter was } \\
\text { applied at all (0=no, 1=yes) }\end{array}$ & -0.419 & 0.341 & 1.510 & 0.219 & 0.658 \\
$\begin{array}{l}\text { Total number of bags of fertiliser } \\
\text { applied }\end{array}$ & 0.083 & 0.038 & 4.666 & 0.031 & 1.087 \\
$\begin{array}{l}\text { Sacks of maize yielded per } \\
\text { household member }\end{array}$ & 1.109 & 0.670 & 2.740 & 0.098 & 3.031 \\
$\begin{array}{l}\text { Percentage of maize consumed } \\
\begin{array}{l}\text { Percentage of maize sold } \\
\hline\end{array}\end{array}$ & -0.034 & 0.008 & 18.049 & 0.000 & 0.967 \\
\hline
\end{tabular}




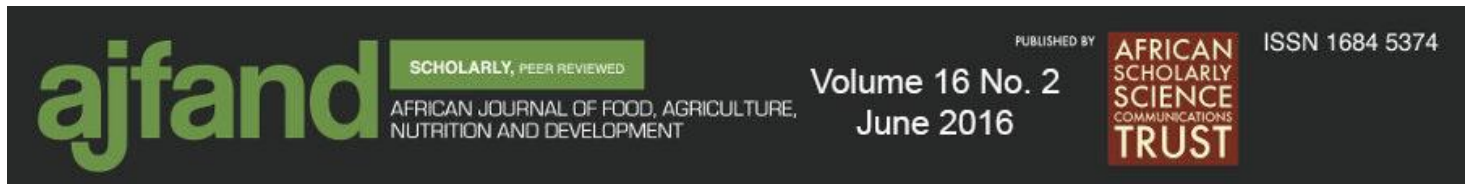

Table 5: Characteristics of credit group members and non-members

\begin{tabular}{llll}
\hline & $\begin{array}{l}\text { Group members } \\
\text { mean, N=101 }\end{array}$ & $\begin{array}{l}\text { Non-members } \\
\text { mean, N=104 }\end{array}$ & $\begin{array}{l}\text { Mann } \\
\text { Whitney P }\end{array}$ \\
\hline Income received from maize sale (Ghana Cedis) & 124.42 & 91.62 & $0.021^{*}$ \\
Income per sack & 52.30 & 51.30 & 0.794 \\
$\begin{array}{l}\text { Bags of fertiliser bought } \\
\begin{array}{l}\text { Bags of fertiliser borrowed from sources other than } \\
\text { credit group }\end{array}\end{array}$ & 0.11 & 4.02 & $0.000^{* * *}$ \\
$\begin{array}{l}\text { Bags of fertiliser used } \\
\text { n }\end{array}$ & 5.90 & 0.36 & 0.333 \\
\hline
\end{tabular}

Table 6: Farmers' comments on subsistence and commercialisation

Percentage of farmers giving each answer to the question 'is maize a subsistence or a commercial crop?' * $\mathrm{N}=205$

\begin{tabular}{lccc}
\hline $\begin{array}{l}\text { Maize is generally only sold if some } \\
\text { remains at the end of the year }\end{array}$ & $\begin{array}{l}\text { Maize can be sold } \\
\text { as well as eaten }\end{array}$ & $\begin{array}{l}\text { Maize is purely a } \\
\text { subsistence crop }\end{array}$ & $\begin{array}{l}\text { Maize is purely a } \\
\text { commercial crop }\end{array}$ \\
\hline 70.2 & 52.9 & 3.4 & 0.5 \\
\hline $\begin{array}{l}\text { Percentage of farmers giving each answer to the question ‘will you buy maize this year?' N=205 } \\
\text { No }\end{array}$ & Maybe & Yes \\
\hline 36.6 & 49.8 & 13.6 \\
\hline
\end{tabular}

*Some farmers gave multiple answers to this open question. The first two responses are not mutually exclusive so the total exceeds $100 \%$ 


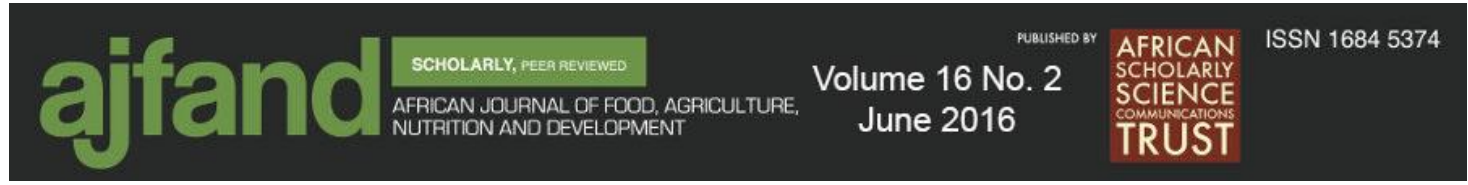

Table 7: Regression coefficients

$\begin{array}{lllll}\text { B } & \text { S.E. } & \text { Wald } & \text { Sig. } & \operatorname{Exp}(B)\end{array}$

\begin{tabular}{lccccc}
\hline Household role $(0=$ not landlord, 1=landlord) & 0.316 & 0.350 & 0.819 & 0.366 & 1.372 \\
Transport (0=no bicycle, 1=bicycle) & -1.180 & 0.596 & 3.911 & 0.048 & 0.307 \\
Asset index score & 0.024 & 0.009 & 6.508 & 0.011 & 1.024 \\
Field location (0=outfield, 1=sambanni) & 24.523 & 0.000 & 0.151 & 0.000 & 6.240 \\
$\begin{array}{l}\text { Group membership (0=not a member, 1=group } \\
\text { member) }\end{array}$ & -0.307 & 0.326 & 0.889 & 0.346 & 0.736 \\
\hline
\end{tabular}




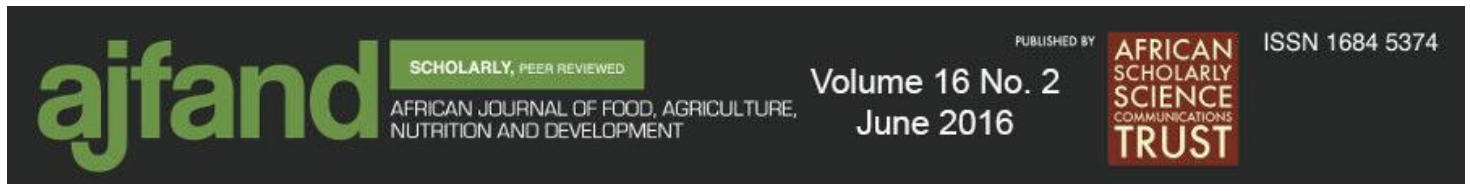

Table 8: Farmers' opinions on credit and fertiliser

\begin{tabular}{|c|c|c|}
\hline Statement & $\begin{array}{l}\text { Number of } \\
\text { farmers }\end{array}$ & $\begin{array}{l}\text { Percentage of } \\
\text { entire sample }\end{array}$ \\
\hline \multicolumn{3}{|l|}{ Positive perceptions about credit and fertiliser } \\
\hline Fertiliser credit improves yields & 188 & 91.7 \\
\hline Fertiliser credit results in less Striga & 6 & 2.9 \\
\hline Fertiliser credit improves soil fertility & 4 & 2.0 \\
\hline Even after taking a loan, farmers benefit & 1 & 0.5 \\
\hline \multicolumn{3}{|l|}{ Ecological concerns } \\
\hline Fertiliser causes problems when rainfall is low & 55 & 26.8 \\
\hline Soil fertility decreases in the years after fertiliser application & 24 & 11.7 \\
\hline Weeds such as Striga appear in the years after application & 10 & 4.9 \\
\hline Fertiliser can be bad for farmer health & 7 & 3.4 \\
\hline \multicolumn{3}{|l|}{ Logistical concerns } \\
\hline Inputs arrive late & 19 & 9.3 \\
\hline Fertiliser is not useful if applied late & 14 & 6.8 \\
\hline \multicolumn{3}{|l|}{ Financial concerns } \\
\hline Repayments are too expensive & 10 & 4.9 \\
\hline The farmer would prefer to be self-sufficient in fertiliser supply & 10 & 4.9 \\
\hline If the crop fails in a drought the farmer cannot repay the debt & 10 & 4.9 \\
\hline The Millennium Development Agency profits more than farmers do & 5 & 2.4 \\
\hline Fertiliser is expensive and unavailable & 4 & 2.0 \\
\hline $\begin{array}{l}\text { Some farmers have not harvested maize by the time repayments are } \\
\text { due }\end{array}$ & 3 & 1.5 \\
\hline Maize market prices are low at the time when repayments are due & 3 & 1.5 \\
\hline Debt repayments are disadvantageous & 1 & 0.5 \\
\hline
\end{tabular}




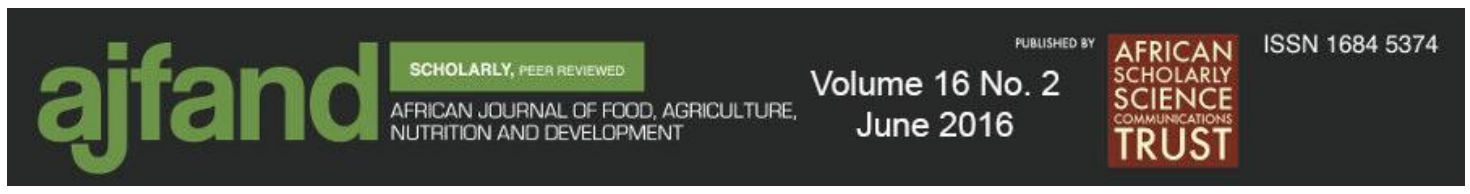

\section{REFERENCES}

1 Sanchez $\mathbf{P}$, Denning $\mathbf{G}$ and $\mathbf{G}$ Nziguheba The African Green Revolution moves forward. Food Security 2009; 1(1): 37-44.

2 Bezner-Kerr R Lessons from the old Green Revolution for the new: Social, environmental and nutritional issues for agricultural change in Africa. Progress in Development Studies 2012; 12(2-3): 213-229.

3 Koopman J Will Africa's Green Revolution squeeze African family farmers to death? Lessons from small-scale high-cost rice production in the Senegal River Valley. Review of African Political Economy 2012; 39(133): 500-511.

$4 \quad$ Nyantakyi-Frimpong $\mathbf{H}$ and $\mathbf{R}$ Bezner Kerr A political ecology of high-input agriculture in northern Ghana. African Geographical Review 2014; 34(1): 13-35.

5 Thompson CB Alliance for a Green Revolution in Africa (AGRA): advancing the theft of African genetic wealth. Review of African Political Economy 2012; 39(132): 345-350.

6 Francis C, Lieblein G, Gliessman S, Breland TA, Creamer N, Harwood R, Salomonsson L, Helenius J, Rickerl D, Salvador R, Wiedenhoeft M, Simmons S, Allen P, Altieri M, Flora $\mathbf{C}$ and $\mathbf{R}$ Poincelot Agroecology: The Ecology of Food Systems. Journal of Sustainable Agriculture 2003; 22(3): 99 118.

7 Holt-Giménez E and M Altieri Agroecology, Food Sovereignty, and the New Green Revolution. Agroecology and Sustainable Food Systems 2012; 37(1): 90102.

8 Yuksel N Achieving a Uniquely African Green Revolution: Report and Recommendations from a high-level conference and seminar at the Salzburg Global Seminar 2008. Salzburg: IDS 2008.

9 Bationo A Constraints and opportunities for achieving a Green Revolution in Sub-Saharan Africa through ISFM. In: The Proceedings of the International Plant Nutrition Colloquium XVI, Davis: UC. Common Market for Eastern and Southern Africa - World Bank 2009.

10 Place F, Barrett CB, Freeman HA, Ramisch J and B Vanlauwe Prospects for integrated soil fertility management using organic and inorganic inputs: evidence from smallholder African agricultural systems. Food Policy 2003; 28(4): 365 378.

11 Jarosz L Growing inequality: agricultural revolutions and the political ecology of rural development. International Journal of Agricultural Sustainability 2011; 10(2): 192-199. 
12 IFDC About AVCMP.

http://www.ifdc.org/Projects/Current2/North_West_Africa/AVCMP_Agricultur al_Value_Chain_Mentorship_Project/About_AVCMP/ (accessed 24 Jul 2014).

13 Guyver P and M MacCarthy The Ghana Grains Partnership. International Journal of Agricultural Sustainability 2011; 9(1): 35-41.

14 GSS. Occupation of employed persons 15 - 64 years by region and district, 2010 2012.

http://www.statsghana.gov.gh/docfiles/occupation_of_employed_persons_1564_years_by_region_and_district_2010.pdf (accessed 8th May 2013).

15 Runge-Metzger A and L Diehl Farm-household systems in Northern Ghana: a case study in farming systems oriented research for the development of improved crop production systems. Nyankpala Agricultural Research Station, Nyankpala. 1993.

16 Bellwood-Howard I Donkeys and Compost Intermediate Transport and Soil Fertility Management in Northern Ghanaian Livelihoods: Thesis submitted to Kings College London for the degree of Doctor of Philosophy. Geography Department, King's College, University of London, London. 2013.

17 Karbo N and W Agyare Crop Livestock Systems in Northern Ghana. In: Tarawali S (ed.) Improving crop-livestock systems in the dry savannas of West and Central Africa. Ibadan: IITA, 2002:112-126.

18 Keil A, Saint-Macary C and M Zeller Agricultural Commercialisation in the Uplands of Northern Vietnam: How to Achieve Both Poverty Reduction and Environmental Sustainability Goals? GEWISOLA, Braunschweig 2011.

19 Ritchie J and J Lewis Qualitative Research: a Guide for Social Science Students and Researchers. Sage London 2013.

20 Sapsford R Survey Research. Sage London 2007.

21 Kennedy $\mathbf{E}$ and B Cogill Income and nutritional effects of the commercialisation of agriculture in Southwestern Kenya. IFPRI, Washington, 1987. Report 63.

22 Chitonge $\mathbf{H}$ and $\mathbf{L}$ Ntsebeza Land Reform and Rural Livelihood in South Africa: Does Access to Land Matter? Review of Agrarian Studies 2008; 2(1).

23 Filmer D and L Pritchett Estimating wealth effects without expenditure data or tears: an application to educational enrolments in states of India. Demography 2001; 38(1): 115-132.

24 Moser C and A Felton The Construction of an Asset Index: Measuring Asset Accumulation in Ecuador. Chronic Poverty Research Centre working Paper 87. The Brookings Institution Washington D.C. 2007. 


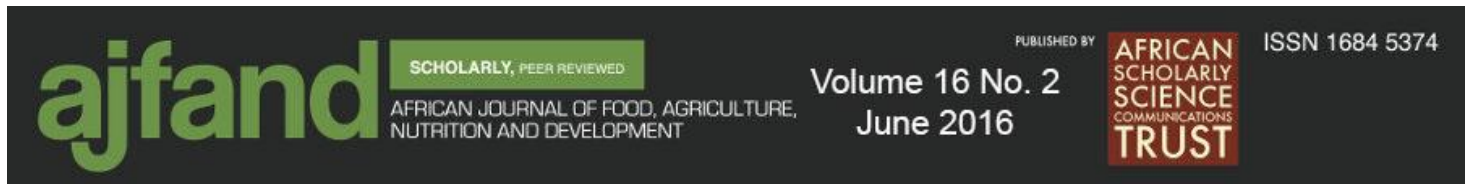

25 Falkingham $\mathbf{J}$ and $\mathbf{C}$ Namazie Measuring health and poverty: a review of approaches to identifying the poor. DfID London 2002.

26 Mabe F, Sienso G and S Donkoh Determinants of Choice of Climate Change Adaptation Strategies in Northern Ghana. Research in Applied Economics 2014; 6(4): 74-94.

27 Bellwood-Howard I Donkeys and bicycles: capital interactions facilitating timely compost application in Northern Ghana. International Journal of Agricultural Sustainability 2012; 10(4): 315-327.

28 Jayne TS, Yamano $\mathbf{T}$ and $\mathbf{J}$ Nyoro Interlinked credit and farm intensification: evidence from Kenya. Agricultural Economics 2004; 31(2-3): 209-218.

29 Giller KE, Rowe EC, de Ridder $\mathbf{N}$ and $\mathbf{H}$ van Keulen Resource use dynamics and interactions in the tropics: Scaling up in space and time. Agricultural Systems 2006; 88(1): 8-27.

30 Van Keulen H (Tropical) soil organic matter modelling: problems and prospects. Nutrient Cycling in Agroecosystems 2001; 61(1-2): 33-39.

31 Bornstein D The social realities of technology transfer: smallholder farmers' encounter with a new rice variety. African Geographical Review 2014; 34(1): 812. 